\title{
The Saddest Man in the World
}

Jack Rintoul

THE BAR WAS cold and smelled of booze. The window was broken, and it was raining in the wind.

Olivia was singing and drew patterns, just as softly, in the wine she had spilled on the table.

I had known her ten years and loved her some. Now we knew how to share silence.

A man blew into the bar. The man was thin and weak. The man was old. His eyes were grey, lonely, full of water. He looked at us, and he did not. He was the saddest man in the world.

He slipped through the room, slid onto a stool and sopped down on the bar. He dripped on the floor and the bartender did not mind.

Olivia turned and grinned at me.

'I wonder what life as an alcoholic would be like.' I lit a cigarette.

'Not all that wonderful.'

Outside, in the street, cars were carving through rain. I could hear the tyres turning over the cold road.

'Are you okay?'

Cars were cresting hills in the dark, high beams on the highway, stretched out at a-hundred-and-fifty.

'Why wouldn't I be okay?'

'Don't be like that.'

'Ok, I won't.'

The bartender put a beer in front of the saddest man in the world.

'Maybe I'll visit you over there,' I said. 
The saddest man in the world picked it up and sipped from it dutifully.

'You have to.' She had a greedy glint in her eye. 'You have to come visit. I'll take you to the Met and show you how to get around on the subway. I'll show you uptown and downtown and how nice Harlem is now. We can go to the good bars and then the bad ones. There won't be much room at our apartment but we'll lay out a mat for you. It will be warm, I promise. In the morning I can make us all breakfast and we'll go get black coffee before I go to work and then you can catch the ferry with -

The saddest man in the world screamed.

He writhed off his stool and dropped to the floor. I ran to him, knelt over him and shook his shoulders. 'What's wrong?'

His lips bubbled and spat.

'What's wrong with you?'

His eyes popped, rolled, and there on the floor with my arms around him, the saddest man in the world died.

He had not said one word. I had not known his name and he had not known mine. His head hung from his shoulders. I looked at him, and I did not. I cradled his body, still cold from the rain.

'He'll be alright,' said the barman. 'Just leave him alone a few minutes.'

The saddest corpse in the world emitted a small moan. So he wasn't dead. The cheat! The liar! The saddest bastard in the whole world! I dropped him to the boards.

The barman leaned over the bar and looked at the saddest resurrected corpse in the world.

'He does this every Friday.'

He squeezed his barcloth over the man.

I returned to Olivia. She was enjoying herself very much.

'That was fun.'

'Better than the movies,' I said.

'Better than a show,' she said.

The room went black.

Movement. Sound. A sudden burst of light.

It roared down upon the saddest man in the world.

He sat. He rose to his feet. He was silhouetted in silver.

As we watched, he opened his mouth, took a long, clear breath, and began the most mournful, most beautiful song I had ever heard. 
He ignored the barman, the patrons and the room. His voice was clean and powerful and it was all there was. He sang of joy and bitterness, of happiness and misery, of love and fear.

The room expanded; his cavern; his stage. He was the centre of the universe and time, a dark star, pulling all matter into himself and radiating his song to the void. He was the first person to sing; all others were pretenders.

His voice was the voice of my father, my mother, my self and my other. It drowned out the world. Tears began to swell in me. All things that had confused me became clear, all my regrets were forgiven, all my futures, validated. I was not alone. I was not lost. I was neither, and would never be.

The saddest man in the world stuttered.

The lights came back on. The chef, who had been holding a portable fluorescent, switched it off and went back into the kitchen. The barman picked up a glass and turned it around a cloth.

The saddest man in the world stood, barely, once again another drunk, marooned in his own life.

He fell to the floor and lay very still.

'That was nice.' Olivia hummed the tune.

I felt as if I'd been drinking petrol. I felt sick, corroded, combustible. I stubbed out the cigarette I had been smoking for fear that I would turn into ash in front of Olivia.

'What time is your flight?'

'Early.'

'I'll drive you.'

'No, don't do that. I'll get a taxi.'

Cars were bursting into flames, screaming like meteors down the median line.

'Don't be silly.'

She smiled at me.

'Can I have a kiss?'

The saddest man in the world had approached unseen. His breath smelled of wine. His knees buckled and he caught the back of Olivia's chair to steady himself. His eyes begged her.

'You want to kiss me?'

'Yes, please, just a little kiss. You're the most beautiful girl in the world.' Olivia took his hand from the chair and broke his heart.

'I don't want to kiss you.' 
The saddest man in the world gathered what was left of himself and walked out of the bar, sobbing quietly.

Olivia was calm and happy. She sipped her wine and caught my eye and I wanted very much to leave.

I went to pay for our drinks.

'Do you want some money?' Olivia offered.

I paid for our drinks and gave Olivia's money to the bartender. 'The next time that man comes in, can you buy him a drink for me?' The bartender laughed and nodded.

'See you next time.'

We took the freeway home. The traffic was bad and the fumes were bad but I kept the window down. I wanted the rain on my face.

'Will you miss me?'

The rain was cold and felt like bullets. It was good.

'Of course I'll miss you.'

'You'll come visit me?'

'Probably.'

'You're getting all wet.'

I was burning. The rain was good.

'I want you to come over for my birthday. You can meet Luke before the wedding.'

I saw police lights ahead, flashing blue in the red sea of brake light in front of us. I saw flames, a tarpaulin flapping, and a tall pillar of smoke billowing black into the sky. The cars sank toward a bottleneck and I felt it, felt the rain on my face, smelled the smoke; somebody had died.

We passed by the crash site. A mangled car, a stretcher bearer, a sheet pulled back by the wind. That bloody face. The saddest face. The saddest man in the world. 